\title{
Erratum to: 39th ESCP European symposium on clinical pharmacy \& 13th SFPC congress: clinical pharmacy at the front line of innovations. 21-23 October 2010, Lyon, France
}

\section{Erratum to: Int J Clin Pharm (2011) 33:285-467 DOI 10.1007/s11096-011-9481-6}

\author{
Abstracts \\ ERRATUM-This abstract should have been included in the \\ abstract set.
}

\section{CPK-5}

Vancomycin dose adjustment in obese patients

A. Estefanell ${ }^{1, *}$, G. Riu ${ }^{1}$, D. Soy ${ }^{1}$, C. Codina ${ }^{1}$, J. Ribas ${ }^{1}$

${ }^{1}$ Hospital Pharmacy, HOSPITAL CLÍNIC, BARCELONA, Spain

Introduction Multiple pharmacokinetic (PK) studies have demonstrated that total body weight is the best method to dose vancomycin. However, clinicians usually prescribe the standard dose of antibiotic $(1 \mathrm{~g} / 12 \mathrm{~h})$, independently of weight.

The aim of this study is to obtain the percentage of obese patients treated with vancomycin at the standard doses of $1 \mathrm{~g} / 12 \mathrm{~h}$ with suboptimal serum concentrations.

Materials \& Methods Study conducted at 800-bed University General Hospital.

Observational study from July 2009 to May 2010 in (1) obese patients (BMI $\geq 30 \mathrm{~kg} / \mathrm{m}^{2}$ ), (2) with creatinine clearance (Clcr) $>50 \mathrm{ml} / \mathrm{min}$ and (3) monitored for vancomycin concentrations after the third dose of antibiotic (dosage: $1 \mathrm{~g} / 12 \mathrm{~h}$ ).

Individual PK parameters were estimated by assuming a bicompartmental PK model and Bayesian forecasting (PKS ${ }^{\circledR}$ Abbot Software). Afterwards, daily dose was adjusted to achieve a minimum vancomycin concentration at steady state $\left(\mathrm{C}_{\mathrm{min}}^{\mathrm{SS}}\right)$ of $7-15 \mathrm{mg} / \mathrm{l}$ and a maximum vancomycin concentration at steady state $\left(\mathrm{C}_{\max }^{\mathrm{SS}}\right)$ of $20-40 \mathrm{mg} / \mathrm{l}$, in case of bacteraemia, or $\mathrm{C}_{\min }^{\mathrm{SS}}$ of $15-20 \mathrm{mg} / \mathrm{l}$ and $\mathrm{C}_{\max }^{\mathrm{SS}}$ of $30-40 \mathrm{mg} / \mathrm{l}$, in case of meningitis, pneumonia, osteomyelitis, wound infection or abscesses.

Data reviewed were: (1) demographics; (2) vancomycin serum concentrations withdraw $30 \mathrm{~min}$ before dose $\left(\mathrm{C}_{\min }^{\mathrm{SS}}\right)$ and $2 \mathrm{~h}$ after ending antibiotic infusion $\left(\mathrm{C}_{\max }^{\mathrm{SS}}\right)$ and (3) individual PK parameters.

Results Ninety-one patients were recruited. Only 37 out of 91 patients fulfilled the inclusion criteria. Demographic data: 54\% men (20 patients), age (mean $\pm \mathrm{SD}$ ) $62.8 \pm 12.0$ years, weight $95.9 \pm$ $17.2 \mathrm{~kg}$, BMI $35.2 \pm 5.2 \mathrm{~kg} / \mathrm{m}^{2}$, Clcr $70.1 \pm 17.1 \mathrm{ml} / \mathrm{min}$. Observed vancomycin serum concentrations after 3 doses of $1 \mathrm{~g} / 12 \mathrm{~h}$ : mean $\mathrm{C}_{\mathrm{min}}^{\mathrm{SS}}$ $7.0 \pm 3.3 \mathrm{mg} / \mathrm{l}$, mean $\mathrm{C}_{\max }^{\mathrm{SS}} 16.4 \pm 5.7 \mathrm{mg} / \mathrm{l}$. Individual drug $\mathrm{PK}$ parameters (mean $\pm \mathrm{SD}$ ): steady-state volume of distribution $59.6 \pm 13.4 \mathrm{l}$, total clearance $6.1 \pm 2.0 \mathrm{l} / \mathrm{h}$.

Dose increase was needed in 27 patients $(73.0 \%): 1,000 \mathrm{mg} / 6 \mathrm{~h}$ was set in 1 patient, $1,250 \mathrm{mg} / 8 \mathrm{~h}$ in 2 patients, $1,000 \mathrm{mg} / 8 \mathrm{~h}$ in 15 patients and $1,250 \mathrm{mg} / 12 \mathrm{~h}$ in 9 patients. Dose decrease to $750 \mathrm{mg} /$ $12 \mathrm{~h}$ was needed in 3 patients $(8.1 \%)$. Six patients $(16.2 \%)$ remained with the initial regimen, and in 1 case $(2.7 \%)$, vancomycin was switched to linezolid because of Staphylococcus aureus methicillinresistant pneumonia.

Discussion, Conclusion Results indicate that a high percentage of the patients included were underdosed $(75.7 \%)$. Monitoring serum concentrations of antibiotic is necessary to adjust vancomycin dose to achieve therapeutic concentrations at the target infection site.

\section{Bibliographic references}

1. Alvarez F, Olaechea P, Grau S, Marín M, Domínguez A, Martínez-Lanao J, Soy D et al. Recomendaciones para la monitorización de antibióticos en pacientes críticos ingresados en UCI. Farm Hosp. 2008;32(2):113-23.

2. Hall R, Payne K, Bain A, Rahman A, Nguyen S, Eaton S, et al. Multicenter Evaluation of Vancomycin Dosing: Emphasis on Obesity. The American Journal of Medicine (2008) 121: 515-18.

Keywords Dose adjustment, Obese patients, Vancomycin

The online version of the original article can be found under doi:10.1007/s11096-011-9481-6. 